\title{
The agentive construction in Baltic and Fennic
}

\author{
Axel Holvoet \\ Vilnius University
}

Anna Daugavet

Vilnius University and St Petersburg University

Biruté Sprauniené

Vilnius University

Asta Laugaliené

Vilnius University

The article deals with the agentive construction, a construction identifying the agent used mainly in adnominal position and in the position of nominal predicate but distinct from the agented passive. The notion is known from Finnish grammar (where it has dedicated morphological marking, the agentive participle), but the article describes a similar construction in Latvian. The marking of the agent in the Fennic and Baltic agentive construction is possessive, which points to an areal convergence. The article offers a corpus-based analysis of the lexical input and the semantics of the Latvian agentive construction and discusses the relationship between the agentive construction and the resultative passive. Attention is also given to intra-Baltic historical processes, notably to mechanisms of the rise of an agented passive in Lithuanian from an original agentive construction as retained in Latvian.

Keywords: agent, agentive construction, passive, resultative passive

\section{Passives and agentive constructions ${ }^{1}$}

Agent phrases are mostly associated with the passive (though they can often occur in constructions in which no passive morphology is present), and they are an essential constitutive part of the so-called agented passive. In

\footnotetext{
${ }^{1}$ We wish to thank two reviewers for their constructive criticisms and suggestions, Ksenia Shagal for her advice on Finnish, and Peter Arkadiev, Rolandas Mikulskas, Nicole Nau and Wayles Browne for their useful comments. For all remaining shortcomings of the article we are solely responsible. This research has received funding from the European Social Fund (project No. 09.3·3-LMT-K-712-01-0071) under grant agreement with the Research Council of Lithuania (LMTLT).
} 
constituency-based descriptions of English grammar it is usually assumed that a passive participle with its agentive complement can both be used adnominally (this is called a bare passive in Huddleston \& Pullum, eds., 2001, 1430) and embedded in a larger verb phrase headed by an auxiliary to yield a sentential passive:

(1) The number of [ships [sunk by the enemy]] is not known.

(2) All our ships [were [sunk by the enemy]].

But we also find constructions identifying the agent or, more specifically, the maker of an object, that can be used adnominally or in predicative position without, however, being used in the passive:

(3) He lives within an invisible cage of his own forging, sealed in by his own actions outward... ${ }^{2}$

(4) The smith looked at the blade and his eyes went wide, for it was of his own forging. ${ }^{3}$

We will call a structure like of his own forging an agentive construction, reserving the more common term 'agent phrase' for the structure that can be used in a passive construction as in (2). The term 'agentive construction' is taken from Finnish grammar. ${ }^{4}$

In this article we will be concerned with agentive constructions that display the properties of the phrase of his own forging in (4) and (5) in that they can be used adnominally and in predicative position but not as part of an agented passive. After having introduced the notion of agentive construction as used in Finnish grammar, where it is well established, we will go on to discuss a similar construction in Latvian, where its existence was

\footnotetext{
${ }^{2}$ Garry Wills, The Kennedy Imprisonment. A Meditation on Power.

${ }^{3}$ Dylan Doose, Fire and Sword.

${ }^{4}$ At a reviewer's suggestion we have searched for possible competing uses of the term in the literature to the extent that it was accessible to us via the Internet. Most uses of the formulation 'agentive construction' seem to be non-terminological in that they are not intended uniquely to identify a construction but occur in contexts where two competing constructions within a specific grammatical domain are compared and one of them is found to be higher in agentivity than the other (thus, e.g., with reference to competing case frames with perception and emotion verbs in Korean in Chun \& Zubin 1990). The only terminological use of 'agentive construction' was found in Culy (1985), where it applies to a kind of agent noun in the Mande language Bambara, as illustrated in wulu-nyini-la 'dog-searcher' ('dog'+'search'+la), where - $l a$ is the agentive suffix. No other use of the term, however, seems to be better established than the one found in Finnish grammar.
} 
first noted (and compared to the Fennic construction) in Holvoet (2001). The Latvian construction will be discussed in more detail, attention being given to its lexical input and semantic subtypes. The emphasis will be on the predicative agentive construction, which shows a certain functional similarity to the resultative passive (and also a certain formal similarity, as in Latvian both constructions are based on 'be' with the past passive participle), and interacts with it. The study of the agentive construction is therefore also relevant to that of the resultative passive.

The structure of the article is as follows. We will first discuss the Finnish agentive construction in more detail in order to clarify the notion of agentive construction as we use it in this article. Next, we will show that Latvian also has an agentive construction as understood in Finnish grammar, with the same possessive marking for the agent. We will then consider the facts of Latvian's sister language Lithuanian to point out that common Baltic must have possessed an agentive construction as still attested in Latvian, out of which an agented passive developed in Lithuanian. This historical section is followed by a corpus-based analysis of the lexical input and semantic subtypes of the Latvian agentive construction, reflecting successive extensions from the prototypical meaning of authorship. A brief section on Finnish shows that the same types of input and semantic patterns exist in Finnish. The final section deals with Lithuanian, where the agentive construction was integrated into the resultative passive but certain features harking back to it can still be observed.

\section{The agentive construction in Finnish (and Fennic)}

Like the English agentive construction mentioned above, the Finnish agentive construction is not related to the passive. The term 'passive' is reserved, in Finnish grammar, for a class of forms and constructions conveying that "the action of the verb is performed by an unspecified person, i. e. that the agent is impersonal (indefinite)" (Karlson 2002, 72). The present and preterite forms of the passive have affixal markers:

(5) Finnish (Karlson 2002, 178)

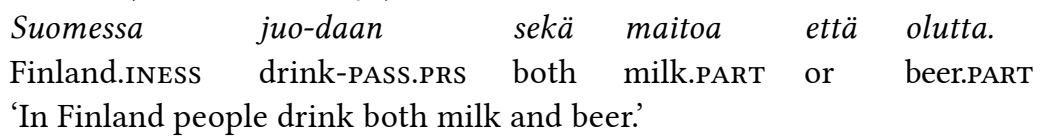


In the perfect tenses, the passive consists of the verb 'be' used as an auxiliary and the past passive participle:

(6) Finnish (Karlson 2002, 178)

$\begin{array}{llll}\text { Kouluissa } & \text { on } & \text { lue-ttu } & \text { saksaa } \\ \text { school.INESS.PL } & \text { be.PRS.3SG } & \text { read-PPP } & \text { German.PART } \\ \text { jo } & \text { pitkään. } & & \\ \text { already } & \text { long } & & \end{array}$

'German has long been studied in the schools.'

It is impossible to add an agent phrase in the Finnish passive. Indeed, the whole construction has also been called impersonal rather than passive, which is probably more accurate (Hakulinen 1957, 174-175, Shore 1988, etc.; cf. Blevins 2003 for the notions of passive and impersonal and Malchukov \& Siewierska 2011 on the agent-defocusing approach to impersonality) even though the discussion is partly terminological. ${ }^{5}$

In Finnish, the forms referred to as 'past passive participles' do not take agentive complements. Finnish has a dedicated type of participles for reference to the agent at noun phrase level, the so-called agentive participle. ${ }^{6}$ It is illustrated in (7) and contrasted with a construction with the past passive participle shown in (8):

(7) Finnish (Karlson 2002, 208)

$\begin{array}{lll}\text { Kallen } & \text { osta-ma } & \text { auto } \\ \text { Kalle.GEN } & \text { buy-AGP[NOM] } & \text { car.NOM } \\ \text { 'the car bought by Kalle' } & \end{array}$

(8) Finnish

$\begin{array}{lcl}\text { juuri } & \text { ostettu } & \text { auto } \\ \text { just } & \text { buy.PPP[NOM] } & \text { car.Nom } \\ \text { 'the/a recently bought car' } & \end{array}$

The agentive participle cannot be used without an explicit agent, which is encoded either as a possessive noun phrase, always preceding the parti-

\footnotetext{
${ }^{5}$ On similar difficulties in the interpretation of the Lithuanian (impersonal) passive see Sprauniené, Jasionytė \& Razanovaitė (2015).

${ }^{6}$ This term is somewhat confusing as it is used in different meanings. Shagal $(2017,57-60)$ uses it to refer to participles that specifically relativise transitive subjects (not necessarily agents) as distinct from intransitive subjects. This would include participles that could be used in a construction meaning 'the dog that bit my son' (where $d o g$ is A) but not in the construction 'the dog that ran away' (where $d o g$ is $\mathrm{s}$ ). In the meaning in which the term is traditionally used in Finnish scholarship, it serves to relativise objects (patients).
} 
ciple and forming a constituent together with it, or by a possessive suffix on the agentive participle. The latter possibility is shown in (9):

(9) Finnish (Karlson 2002, 209)

Istun hankki-ma-ssa-ni veneessä.
sit.PRS.1SG get-AGP-INESS-1SG boat.INESS
'I am sitting in the boat I got.'

The agentive participle is used not only adnominally. It can also be shifted to the position of nominal predicate in a copular sentence:

(10) Finnish (Karlson 2002, 209)

$\begin{array}{llll}\text { Ehdotus } & \text { on } & \text { Virtasen } & \text { esittä-mä. } \\ \text { proposal.NOM.SG } & \text { be.PRS.3SG } & \text { PN.GEN } & \text { put.forward-AGP } \\ \text { 'The proposal was put forward by Virtanen.' } & \end{array}$

A third position in which the agentive construction occurs is that of a secondary predicate. (11) has an instance of a 'detached predicative', i.e. a syntactically and prosodically loosely integrated secondary predicate (for the term see Biber et al. 1999, 136-137):

(11) Finnish

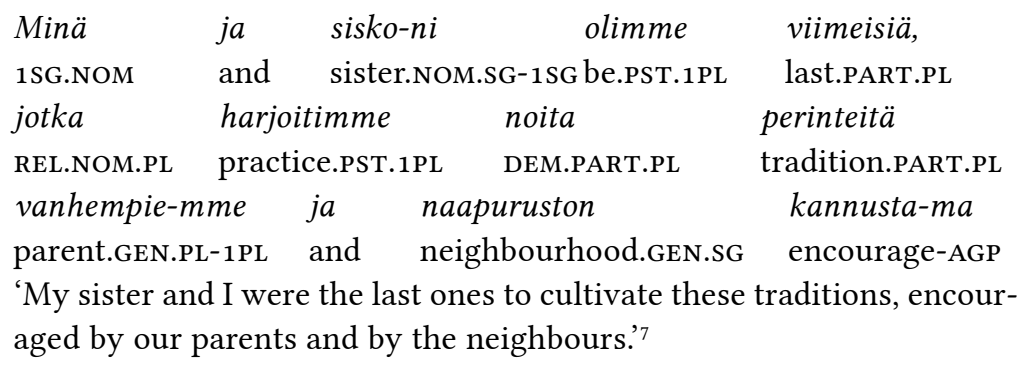

The agentive participle is historically an action noun comparable to English making ${ }^{8}$ so that the whole construction corresponds exactly to the English construction (is) of somebody's making. Sulkala and Karjalainen are careful to render it with this English construction rather than with a passive, cf. example (12), with the original translation:

\footnotetext{
${ }^{7}$ http://harmaajamuutiloisetvarit.blogspot.com/2014/04/

${ }^{8}$ It is also used as an infinitive (the so-called 'third infinitive'). Synchronically, however, the term 'participle' is accurate, as in the agentive construction the form in - $m A$ takes case endings agreeing with the case of the head noun.
} 
(12) Finnish (Sulkala \& Karjalainen 1992, 219)

$\begin{array}{lll}\text { Auto on } & \text { pojan } & \text { teke-mä. } \\ \text { car.NOM be.PRS.3SG boy.GEN.SG } & \text { make-AGP } \\ \text { 'The car is of the boy's making.' } & \end{array}$

It will be noted that the relationship referred to in sentences like (12) is not strictly one of agency, as would be the case in The car was made by the boy. Here reference is made to the enduring relation of authorship that results from previous agency, not to the agency itself, which may belong to a distant past.

However, though satisfactory in prototypical cases like (12), a translation based on the construction ' $\mathrm{x}$ is of $\mathrm{y}$ 's $\mathrm{v}$-ing' is not always adequate in the sense that the Finnish agentive construction is semantically much broader: it extends to situations where no reference is made to authorship, and the argument encoded as possessor is not even an agent:

(13) Finnish (example from Shagal 2017, 17)

$\begin{array}{ll}\text { [eilen tapaa-ma-ni] } & \text { mies } \\ \text { yesterday meet-AGP.NOM.SG-1SG } & \text { man.NOM.SG } \\ \text { 'the man I met yesterday' } & \end{array}$

Here there is no equivalent English construction of the type *the man of my meeting. But Sulkala and Karjalainen's rendering captures the fact that the notion of authorship is the prototype of the agentive construction whereas other types of relationship between the modified noun and the possessively encoded agent or pseudo-agent are extensions from this prototype. Example (13) shows one type of extension: the verb is not agentive any more. In another type of extension, the verb is still agentive but the subject is a force of nature rather than a human author:

(14) Finnish (Hakulinen 1957, 138)

$\begin{array}{lll}\text { virran } & \text { viemä } & \text { vene } \\ \text { current.GEN.SG } & \text { carry.away.AGP } & \text { boat.NOM.SG }\end{array}$

'a/the boat carried away by the current'

In standard Finnish, the perfect tenses of the passive and the agent construction can clearly be set apart. In addition to the different morphology, there is a syntactic difference. Basically, the two constructions are complementary: the construction with the past participle cannot take an agentive complement whereas the agentive construction cannot do without it. In the dialects, however, the two constructions are not so clearly distinct. Eastern Finnish dialects have the passive participle instead of the agentive participle: 
(15) Finnish (dialectal; Hakulinen 1960, 294)

$\begin{array}{llll}\text { Tämä on } & \text { hiiren } & \text { syötyä } & \text { leipää. } \\ \text { DEM be.PRs.3SG } & \text { mouse.GEN eat.PPP.part } & \text { bread.part.sG } \\ \text { 'This is bread a mouse has eaten from.' } & \end{array}$

Hakulinen also cites examples where both constructions are used in the same sentence:

(16) Finnish (dialectal; Hakulinen 1960, 294)

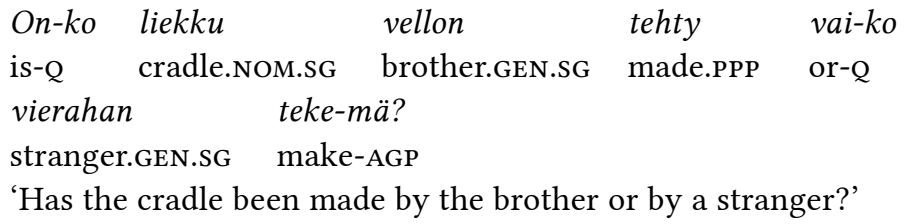

Although in the dialectal varieties of Finnish just mentioned the agentive construction has no dedicated morphological marker, we may assume that even in those varieties it functions as a distinct construction. Presumably at least the following differences obtain:

- the agentive construction has an overt agent phrase with possessive encoding, whereas the 'agent' is always implicit in the passive;

- the implicit subject of a Finnish passive is always human (it could loosely be rendered with the English generalising they), whereas the agentive construction extends to non-human agents like forces of nature, cf. example (9);

- case marking: in the passive the subject (the original object of the active construction) may be in the nominative or in the partitive, whereas in the predicative agentive construction it will normally be in the nominative, as it is typically definite.

A similar situation as in the East Finnish dialects (and in Votic, cf. Ariste 1968, 19) seems to obtain in Estonian, though in Estonian grammar the agentive construction is not singled out as a distinct construction. It is described as one of the varieties of the 'personal passive', which is stative/ resultative (Lindström 2015, 144). Genitive is, as Lindström shows, only one of the ways in which the agent can be encoded in Estonian. She states, however, that "the genitive is different from other agent-marking devices since it belongs syntactically together with the PPP and thus its position in the sentence is fixed" (Lindström 2015, 148). That is, the situation basically corresponds to that in the East Finnish dialects. An example showing the agentive character of the construction: 
(17) Estonian (Otto Wilhelm Masing, 1818, cited in Lindström 2015, 147)

$\begin{array}{lllll}\text { Nemmad ep olle mitte innimesse } & \text { teh-tud. } \\ \text { 3PL.NOM NEG.3 be NEG human.GEN.SG } & \text { make-PPP } \\ \text { 'They are not made by a person.' } & \end{array}$

Summing up our findings for Baltic Fennic, we can say that its agentive constructions are basically of the same type as English (a house) of Tom's building, that is, they originate within the noun phrase and exploit possessive marking to express agency or authorship. This is done partly by means of forms originating as action nouns, as in standard Finnish. Other Fennic languages use their adnominal passive participles, originally adding the agent as a possessor. The original construction is thus of the type 'Tom's built house', which is semantically reanalysed as 'the house built by Tom'. This semantic reanalysis goes hand in hand with a syntactic reanalysis: the originally possessive, now agentive, genitive constitutes a phrase (an agentive construction) together with the participle:

(18) Finnish (dialectal)

\begin{tabular}{|c|c|c|}
\hline [hiiren & syöty] & leipä \\
\hline mouse.GEN.SG & $\begin{array}{l}\text { eat.PPP.NOM.SG } \\
\text { and' }\end{array}$ & bread.NOM.SG \\
\hline
\end{tabular}

The English translation 'mouse-eaten' is chosen for a good reason: the translation 'eaten by a mouse' would suggest the construction is a bare passive corresponding to a sentential passive The bread was eaten by a mouse. But this is not the case: the agentive construction could be used in predicative position, but then the outcome would be comparable to an English construction like (19):

(19) The bread was mouse-eaten.

This is a construction clearly differing from a sentential passive. The verb 'be' would be a copula rather than a passive auxiliary; the whole construction would be akin to a resultative (stative) passive but for the fact that the identification of the agent is an essential element of the construction, which does certainly not hold for resultative passives in general. We will address the question of the status of sentences like (19) and their relationship to the actional and resultative passive below. For the time being, let us note one conspicuous feature setting apart constructions like (19) from passives: the prototypical passive is always agentless, and alongside a sentence like The ships were sunk by the enemy there is always 
a construction like The ships were sunk. In (19), on the other hand, agent phrase and participle form a close-knit unit from which the agent may not be omitted. This has been noted in the literature: for English, for instance, Keenan and Dryer (2007, 344-345) mention what they call incorporation as a strategy for encoding agent phrases. Their example is (20):

(20) The project is state-controlled.

And from Quechua Keenan and Dryer also cite constructions in which the agent "forms a close unit with the verb":

(21) Quechua (Keenan \& Dryer 2007, 345)

$\begin{array}{llll}\begin{array}{l}\text { Kuru } \\ \text { bug }\end{array} \text { eat-PRTC-sqa-mi } & \begin{array}{l}\text { manzana- } \varnothing \\ \text { apple-SBJ }\end{array} & \begin{array}{l}k a-r q a-n \\ \text { be-PST-3 }\end{array} \\ \text { 'The apple was bug-eaten.' } & & \end{array}$

Although the last two examples of strategies for expressing agents are given in the context of the passive (in a subsection dealing with agent phrases), they actually show the need for a study of agentive constructions that are not part of a passive construction but occur basically in adnominal position and in the position of nominal predicate. They involve action nouns or passive participles, and the agent is marked by means of a possessive construction or incorporation; in both instances agent and verbal form make up a close-knit unit that can be moved only as a whole and in which neither constituent can be omitted.

\section{The agentive construction in Latvian}

In this section we will show that Latvian is also among the languages that have an agentive construction that is not part of a passive construction. Latvian has made it into the typological literature as a language without an agented passive - a relative rarity among European languages:

(22) Latvian (Keenan \& Dryer 2007, 331, cited from Budiṇa-Lazdiņa 1966)

$\begin{array}{lll}{ }^{*} E s & t i e k u & m a \bar{c} \bar{l}-t-s \\ \text { 1SG.NOM } & \text { become.PRS.1SG teach-PPP-NOM.SG.M } \\ \text { no } & \text { mātes. } & \\ \text { from } & \text { mother.GEN.SG } \\ \text { Intended meaning: 'I am taught by mother.' }\end{array}$

Here the reader might wonder how we can know that a Latvian agent phrase would be introduced by the preposition no 'from' if it does not exist, 
but the answer is simple. Agented passives as in (22) were a regular feature of the written Latvian language up to the early zoth century. They were, however, ousted from the standard language in the 2oth century, apparently under the influence of the leading philologist Jānis Endzelins, on the grounds that this agented passive was a calque from German, alien to the 'unadulterated' popular language as it was reflected in the folk songs (no being a rendering of German von); but see Nau \& Holvoet (2015, 13-14). Texts from the early zoth century still regularly display agent phrases with no:

(23) Latvian (Rūdolfs Blaumanis, 1863-1908, Andriksons, 1899)

\begin{tabular}{|c|c|c|}
\hline $\begin{array}{l}\text { Kas priekš } \\
\text { what.NOM for }\end{array}$ & $\begin{array}{l}\text { manis } \\
\text { 1SG.GEN }\end{array}$ & $\begin{array}{l}\text { mana } \\
\text { my.GEN.SG.M }\end{array}$ \\
\hline aiztaupīts, & man & no tèva \\
\hline ave.up.PPP.NOM.SG. & 1SG.DAT & father.GEN.SG \\
\hline atstāts, & tas & mans. \\
\hline ave.PPP.NOM.SG.M & that.NOM.SG.M & be.PRS.3 mine.NOM.SG.M \\
\hline
\end{tabular}

However, all varieties of Latvian - both the 'unspoilt' popular language of the folk songs and the literary language-do have overtly expressed agents with past passive participles. ${ }^{9}$ They are, however, not used in agented passive constructions as illustrated in (23). They occur in the same positions described above for Finnish, viz. in adnominal participial phrases (24), and participial phrases in the position of nominal predicate (25):

(24) Latvian (lvTenTen14)

\begin{tabular}{llll} 
Pilsētas & iedzīvotāju & iemīlota & \multicolumn{1}{c}{ tikšanās } \\
city.GEN.SG & dweller.GEN.PL & love.PPP.NOM.SG.F meeting.GEN.SG \\
vieta & skvērā & ir & strūklaka \\
place.NOM.SG & square.LOC.SG & be.PRS.3 & fountain.NOM.SG \\
[-meitenes skulptūra ar liliju]. & &
\end{tabular}

'A meeting place on the square beloved by the city dwellers is the fountain [in the shape of a girl with a lily.]'

\footnotetext{
${ }^{9}$ The term 'past passive participle' is mainly historically motivated, as it does not really have past tense meaning: the passive construction tiek veidots 'is being shaped' has a past passive participle, but it has the value of a present tense. What is called the present passive participle is never used in the passive construction. It usually has modal meaning, e.g. ir veidojams (be.PRS.3 shape.PPRP.NOM.SG.M) could mean 'can be shaped' or 'has to be shaped'.
} 
(25) Latvian (lvTenTen14)

$\begin{array}{llcc}\text { Jebkura } & \text { sabiedrības } & \text { iekārta } & \text { ir } \\ \text { any.NOM.SG.F } & \text { society.GEN.SG } & \text { order.NOM.SG } & \text { be.PRS.3 } \\ \text { cilvēku } & \text { veidota, } & \text { nevis } & \text { dabas } \\ \text { human.GEN.PL } & \text { shape.PPP.NOM.SG.F } & \text { rather.than } & \text { nature.GEN.SG } \\ \text { dota. } & & & \\ \text { give.PPP.NOM.SG.F } & & & \end{array}$

'Any social order is shaped by people rather than given by nature.'

A third position in which the agentive construction occurs is that of secondary predicate - integrated (26) or detached (27):

(26) Latvian (lvTenTen14)

Neviens tajās nestājas nesavtīgu,

nobody.NOM 3.LOC.PL.F NEG.join.PRS.3 unselfish.GEN.PL

augstāku mērķu vadīts,

higher.GEN.SG purpose.GEN.PL guide.PPP.NOM.SG.M

[bet ar domu tikt pie kāda ienesīga amata.]

'Nobody joins them [those organisations] guided by unselfish

higher purposes [but only in order to get a lucrative job.]'

(27) Latvian (lvTenTen14)

Meitene, tantes mudināta,

girl.NOM.SG aunt.GEN.SG encourage.PPP.NOM.SG.F

atbildējusi,

answer.EVID.PST.SG.F

[un tā apmèram gadu ceḷojušas sirsnīgas vēstules].

'The girl, encouraged by her aunt, reportedly answered,

[and so cordial letters appear to have been exchanged for about a year.]'

The constructions with the agentive construction in the position of secondary predicate will not be our primary concern in this article. We will mainly deal with the constructions illustrated in (24) and (25), and will correspondingly distinguish the 'adnominal agentive construction' illustrated in (24) and the 'predicative agentive construction' illustrated in (25).

An attempt at introducing an agent phrase of the type illustrated in (25) into the standard dynamic (actional) passive, formed with the aid of the auxiliary tikt 'become', yields a result not acceptable in the established standard language (though constructions of this type are beginning to appear on the Internet): 
(28) Latvian

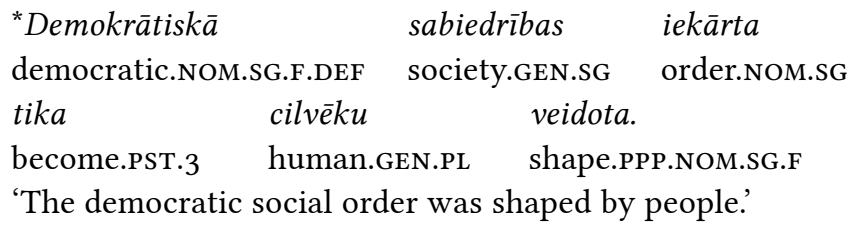

In addition to passives with tikt 'become', Latvian has two types of passive constructions with the verb 'be'. One is the passive perfect, which arises from the optional deletion of ticis/tikusi..., which is the active participle of tikt, the auxiliary of the passive. It is illustrated in (29), where we have a passive experiential perfect (for the notion of experiential perfect cf. Dahl 1985, 132, passim). The full form would be ir ticis redzēts (be.PRs.3 become.PPA.NOM.SG.M see.PPP.NOM.SG.M). The other type is the resultative (stative) passive, as in (30):

(29) Latvian

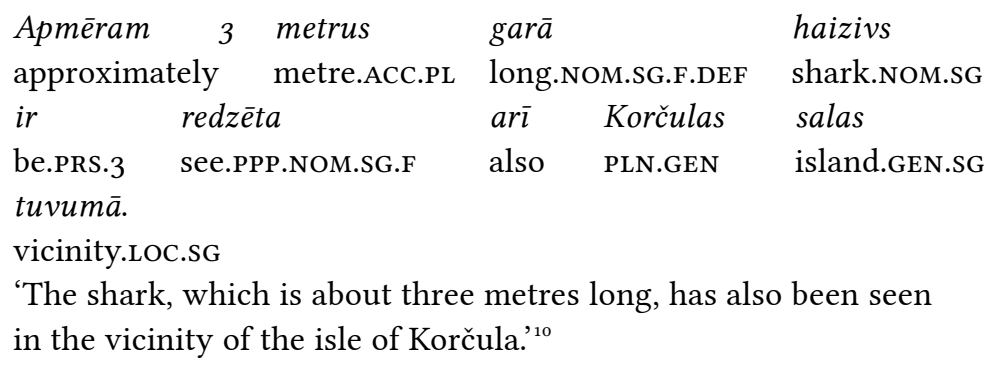

(30) Latvian

\begin{tabular}{|c|c|c|c|}
\hline $\begin{array}{l}\text { Rihards Melgailis } \\
\text { PN }\end{array}$ & $\begin{array}{ll}\text { informe }, & k a \\
\text { inform.PRs.3 } & \text { that }\end{array}$ & $\begin{array}{l}\text { Vecumniekos } \\
\text { PLN.LOC.PL }\end{array}$ & $\begin{array}{l}\text { nodal̦a } \\
\text { branch.NOM.sG }\end{array}$ \\
\hline jau & nodibināta. & & \\
\hline already & found.PPP.NOM & & \\
\hline
\end{tabular}

As can be seen from these examples, the predicative agentive construction is less easy to set apart from the passive construction than is the case in standard Finnish. In particular, the question should be posed what its

\footnotetext{
${ }^{10} \mathrm{http} / / /$ travelnews.lv/?m_id=18311\&i_id=5\&pub_id=117037

${ }^{11}$ http://www.bauskasdzive.lv/vietejas-zinas/vecumniekos-izveidota-regionualianses-nodala-3585
} 
relationship is to the resultative passive as illustrated in (30). It is clear that the two constructions arise separately: the predicative agentive construction arises when a participial phrase containing a genitival agent, originating in adnominal position (the genitive being originally possessive) is shifted to predicative position. At this stage the construction starts to interact with the resultative passive, which basically serves a different function from the agentive construction: its purpose is to describe the result of an event, not the authorship of an object. It has been observed in the literature that resultative passives are typically agentless, though exceptions have also been noted. This will be discussed below. For the time being let us note that, whatever the extent of interaction between agentive construction and resultative passive may be, the two can, in Latvian, be set apart clearly: whatever contains a genitival agent is an agentive construction, whatever does not is a resultative passive.

\section{From agentive construction to agented passive}

While the agentive constructions discussed until now are not part of passive constructions, they are, of course, susceptible of undergoing the influence of the passive construction and of being integrated into it, yielding an agented passive. This has actually happened in Latvian's sister language Lithuanian. It has long been recognised that the genitive encoding the agent with passive participles in both Lithuanian and Latvian is of possessive origin, cf. Endzelin (1923, 416), Fraenkel (1928, 95), Ambrazas (2006) etc. Even in modern Lithuanian, the possessive origin of the agentive genitive can still be seen from the form of personal pronouns used with the passive participles. 1st and 2nd singular personal pronouns and the reflexive pronoun have two forms for the genitive: one is used when governed by verbs, the other is possessive and is used adnominally, but also in the agentive construction.

(31) Lithuanian

[Neatsako ị skambučius ir žinutes,]

vienu žodžiu vengia manęs,

one.INS.SG.M word.INS.SG avoid.PRS.3 1SG.GEN

[nes nenori atiduoti skolos.]

'He doesn't answer my phone calls and mails, in brief - he avoids me [because he doesn't want to pay back his debt.] ${ }^{12}$

${ }^{12}$ http://www.lietuviai.se/frm/viewtopic.php?f=9\&t=1381 


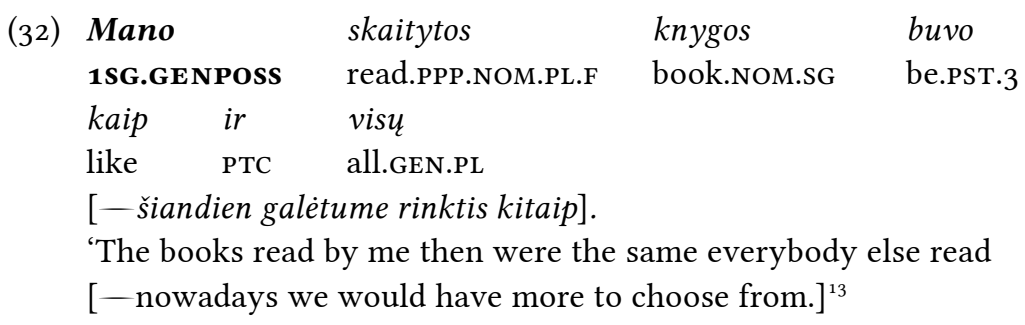

Moreover, in Latvian, which has no special possessive genitival forms of the personal pronouns, a possessive pronoun agreeing with the subject in number and gender, as in (33), can be used instead of the more common personal pronoun shown in (34). The marking of the agent by means of a possessive pronoun rather than a noun phrase is reminiscent of the use of possessive suffixes on the agentive participle in Finnish, as illustrated in (9) above.

(33) Latvian (cited from Nau 2016, 497)

Vērojot, $k \bar{a}$ cilvēkiem patìk mani

observe.PRS.CVB how person.DAT.PL please.PRS.3 my.NOM.PL.M

audzētie ziedi, es gūstu

grow.PPP.NOM.PL.M.DEF flower.NOM.PL 1SG.NOM gain.PRS.1SG gandarījumu.

satisfaction.ACC.SG

'Seeing how people like the flowers I grow, I gain satisfaction.'

(34) [Cilvēki mani pazīst, uzticas manai produkcijai.]

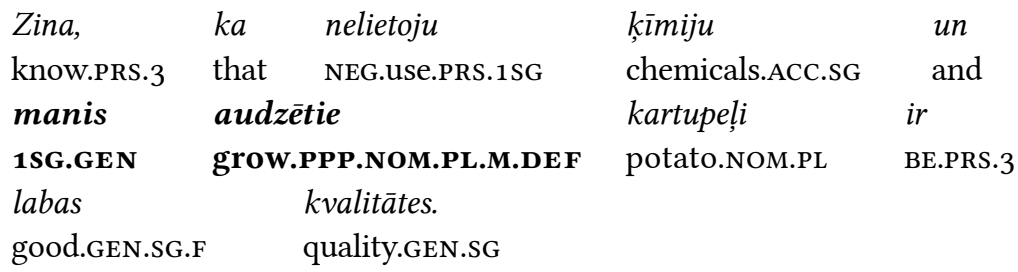

'[People know me, they trust < the quality of $>$ my goods.] They know that I don't use chemical fertilisers and the potatoes I grow are of good quality.' ${ }^{14}$

\footnotetext{
${ }^{13}$ https://rubinaitis.lnb.lt/index.php?3215546684. Note that a purely possessive reading of mano in sentences like this is still possible.

${ }^{14}$ http://laukos.la.lv/jauno-kartupelu-raza-sogad-laba-tirgu-dargak-neka-pern
} 
As explained above for Finnish, the development from possessive to agentive meaning involved a syntactic reanalysis: [mani [audzètie ziedi]] 'my grown flowers' became [[mani audzētie] ziedi] 'flowers of my growing, the flowers grown by me'. This agentive construction [mani audzètie] could then be moved to predicative position. In Latvian, the development stopped at this point. In Lithuanian, however, the process went further and the genitival agent extended to full dynamic agentive passives:

(35) Lithuanian

[Spalio 31 d., pirmadieni, policija gavo triju senoliu skundus,]

kad buvo apgauti telefoniniu

that be.PRS.3 deceive.PPP.NOM.PL.M telephone.ADJ.GEN.PL

sukčiur.

impostor.GEN.PL

'[On Monday, October 31, the police received three complaints

from elderly people saying] they had been deceived by telephone impostors. ${ }^{15}$

This process has been studied in some detail by Ambrazas (2001, 2006). According to him, the full agented passive based on transitive verbs, expanded with genitival agent phrases, developed initially in the Western Lithuanian dialects. Attestations can already be found in Old Lithuanian, as shown in (36). However, Old Lithuanian texts always reflect the influence of foreign sources (Latin, German, Polish) and provide countless examples of agents expressed by prepositional phrases with nuo, considerably outnumbering the attestations of the genuine Lithuanian construction with the bare genitive; an example is given in (37).

(36) Old Lithuanian (Bretkūnas, Postil II 191.6-8, cited from Ambrazas 2006, 181)

Vbagas numire ir tapa neschtas

beggar.NOM.SG die.PST.3 and become.PST.3 carry.PPP.NOM.SG.M

Angelu ing prieglobsti Abrahamo

angel.gen.PL into refuge.ACC.sg Abraham.geN

'The beggar died and was carried by angels into Abraham's bosom.'

${ }^{15}$ https://www.delf.lt/news/daily/crime/siauliuose-nerimsta-telefoniniai-sukciai-kencia-patiklussenoliai.d?id $=72732700$ 
(37) Old Lithuanian (Vilentas, Gospels and Epistles 5.5-6,

cited from Ambrazas 2006, 183)

[Aesch vschmaszausi daikta laikau]

idant nůg yussu buczia suditas.

that by 2PL.GEN be.IRR.1SG judge.PPP.NOM.SG.M

'[With me it is a very small thing] that I should be judged by you.'

In East Lithuanian, on the other hand, agentive genitives were introduced mainly in constructions with intransitive verbs. The construction developed an evidential function:

(38) Lithuanian (cited from Ambrazas 2006, 186)

$\begin{array}{llll}\text { Čia turbūt ir grybu } & \text { esama. } \\ \text { here probably PTC mushroom.GEN.PL } & \text { be.PPRP.N } \\ \text { 'There probably must even be mushrooms here.' } & \end{array}$

More recent authors have argued that such constructions, though historically connected with the passive as well as with the agentive construction, cannot synchronically be recognised as passive because they lack a number of defining features of the passive (Lavine 2006, Holvoet 2007). They should therefore be recognised as a distinct evidential construction parasitic, for its morphology, on the passive construction.

How is the process of the rise of an agented passive from the agentive construction to be interpreted syntactically? The most obvious solution is to assume that in the source construction the agent phrase formed a constituent together with the participle, and that in the course of the syntactic process giving rise to the modern Lithuanian passive it was extracted from the constituent containing the participles to become a clausal constituent. To account for this we might assume that the full passive buvo pastatytas (be.PST.3 build.PPP.NOM.SG.M) 'was built' acquired a new syntactic status. We will call it a verbal 'group', using a term proposed by Huddleston \& Pullum (2001, 1213), though these authors ultimately reject the kind of analysis adopted here. A verb group is not a verb phrase, as it does not yet comprise a complement.

(39) (a)

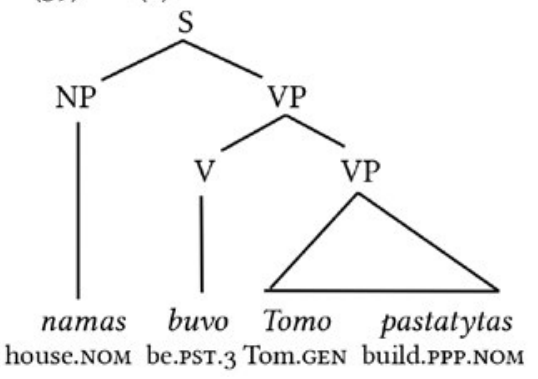

(b)

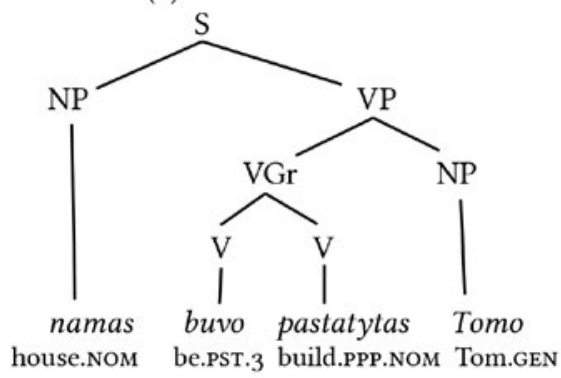


Of course it is clearly the participle that syntactically licences the complement and assigns it genitive case, but it does not seem unreasonable to assume that buvo pastatytas 'was built' and pastatytas 'built' select the same kinds of complements and assign the same case. In Zwicky's (1993) terms, the relationship between finite verb and participle would be that of specifier and base, the base being responsible for external valency and the specifier acting as morphosyntactic locus. This solution is perhaps somewhat lacking in elegance, but not much else is left if one rejects functional projections that would enable one to introduce participial agent phrases in the VP and sentential agent phrases in a functional projection above the VP. In a dependency framework the difference is also difficult to capture in a straightforward way. One way of accounting for the syntactic change would be to invoke, here as well, Zwicky's notion of split or diffuse headedness, with a specifier-base relationship. This is seen in (4ob), where no dependency relation is assumed between auxiliary and participle; the auxiliary is under the clause node $S$ because it carries such clausal features as mood and tense, whereas the arguments of the passive verb are dependents of the participle. Note that a similar solution is adopted for article and noun in Eroms (2000, 253); auxiliary-verb constructions are similar in that they also involve a specifier-base relationship.

(40)

(a)

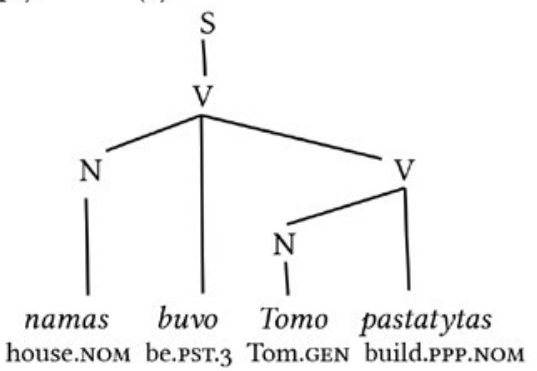

(b)

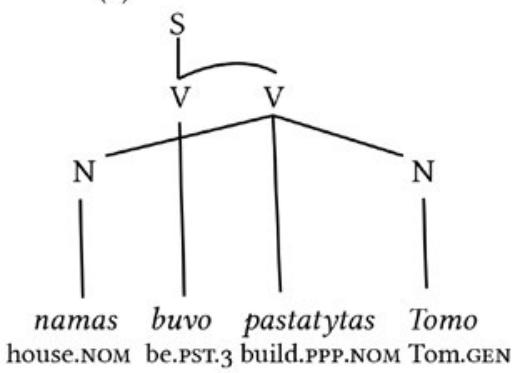

While this development must already have occurred in the prehistory of Lithuanian, a similar development now seems to be going on in Latvian. We find sporadic instances of the introduction of tikt 'become', the auxiliary of the dynamic passive, in the place of 'be', yielding what is obviously a new agented passive; see also Nau \& Holvoet $(2015,14)$. The Latvian Web Corpus (lvTenTen14) yields 91 instances of this. (The results had to be manually selected from a wider set of data representing combinations of a genitive and a following participle that is immediately preceded by the verb tikt; see below for a description of the corpus data). 
(41) Latvian (lvTenTen)

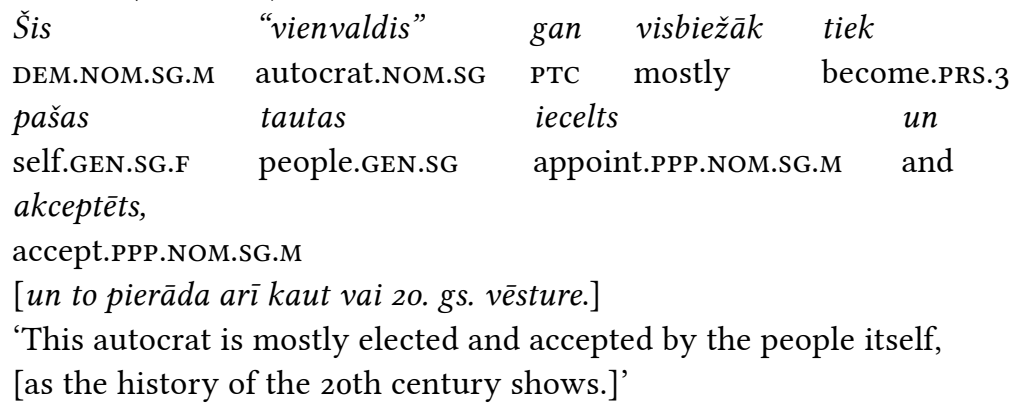

(42) Latvian (lvTenTen)

fézus turp dodas, lai tiktu

Jesus.NOM thither go.PRs.3 in.order.that become.IRR

velna kārdināts.

devil.gen tempt.PPP.NOM.sG.M

'Jesus goes thither [sc. into the desert] in order to be tempted by the Devil.'

This process might lead, in the course of time, to the formation of a full agentive passive in Latvian, analogous to that which developed in Lithuanian centuries ago. This will not automatically mean the end of the agentive construction as such, as it will still differ from the agented passive in the selection of its auxiliary-büt rather than tikt.

\section{The agentive construction in Latvian: the empirical basis}

We will now investigate in greater detail the Latvian agentive construction as it is reflected in two corpora: the Latvian Web Corpus (IvTenTen14) at sketchengine.eu, made of texts collected from the Internet and containing 530 million words, and the Balanced Corpus of Modern Latvian (LVK2013) at korpuss.lv, containing 4.5 million words. Only the fiction subcorpus was searched in LVK2013 in order to compensate for the fact that fiction is poorly represented in lvTenTen14. In both cases our data were obtained by searching for participles that are immediately preceded by a noun in the genitive. Since neither corpus distinguishes among different participles, results were further narrowed by automatically selecting only those lines in which the participle contained the character $<\mathrm{t}>$, corresponding to the passive past participle formative. 
The first thousand lines that were obtained as described above from lvTenTen 14 turned out to contain 514 instances of the agentive construction that had to be extracted manually. This main set of data was further divided into groups corresponding to syntactic position: we distinguished adnominal agentive constructions (483, making up 94\%), predicative agentive constructions $(13,3 \%)$ and agentive constructions used as secondary predicates $(18,4 \%)$. An identical automatic search in LVK2013 produced the total number of 999 lines which, likewise, contained 501 examples of the agentive construction, including 394 instances of the adnominal agentive construction (henceforth AAC), amounting to $79 \%, 14$ instances of the predicative agentive construction (henceforth PAC), making up 3\% of the total number, 93 agentive constructions functioning as secondary predicates $(18 \%)$.

As can be seen from the numbers, the share of PAC is equally small in both corpora. Additional data on OPAC were obtained from lvTenTen 14 by automatically selecting those lines with $<\mathrm{t}>$ where the combination of the genitive with a following participle is immediately preceded by the verb $b \bar{u} t$ 'be'. After removing all extraneous results, the exact number of PAC was found to be 409. It was however impossible to get any data in addition to the above mentioned 14 instances of PAC from LVK2O13 because of the much smaller size of this corpus.

Table 1. Adnominal and predicative agentive constructions in the Latvian corpora

\begin{tabular}{l|l|l}
\hline & \multicolumn{1}{|c|}{ AAC } & \multicolumn{1}{c}{ PAC } \\
\hline IVTenTen14 & $483(94 \%)$ & $13(3 \%)$ \\
LVK2013 & $394(79 \%)$ & $14(3 \%)$ \\
IVTenTen14, additional search & - & $409(100 \%)$
\end{tabular}

We also used additional data on AAC that were obtained from $l v T e n$ Ten 14 by extracting those participles that are immediately preceded by a genitive and end in the character sequences $<$ ts $>,<$ to $>,<$ tiem $>$ etc., corresponding to various case forms.

Separately discussing the semantic properties and lexical input for all three groups (including agentive constructions used as secondary predicates) would be repetitive and unilluminating. We compared the lexical 
input for adnominal and predicative constructions, but this comparison revealed no significant differences; in fact, differences of genre and style proved to be more significant than those of syntactic position. Therefore we have singled out one group of agentive constructions for closer scrutiny, viz. the predicative agentive construction. The reason for this choice (which is not obvious considering the much lower frequency of this type) is mainly practical. We have a number of useful notions to describe the different types of constructions with predicative passive participles, such as 'dynamic passive' and 'resultative passive', whereas no corresponding terminology is available for the corresponding constructions with adnominal participles.

\section{The Latvian PAc:}

\section{Semantic types and lexical input}

As was to be expected, in our materials we found a sizeable group consisting of verbs implying authorship, such as veidot 'form, shape' and sastādìt 'compile'. Such constructions are properly agentive.

(43) Latvian (lvTenTen)

[fāpiebilst, ka tas,]

\begin{tabular}{|c|c|c|c|}
\hline$k a$ & kanāls & & amerikāṇu \\
\hline that & channel.NOM.SG & be.PRS.3 & American.Gen.PL \\
\hline
\end{tabular}

[nekādā ziñā nemaina to, ka tas būs iecienìts arī jūsmājās.]

'It should be added that the fact that the channel is created by Americans [does not in any way damage its prospects to be popular at your home as well.]'

This is a typical agentive construction in the sense that agentivity is presupposed and the identity of the agent is emphasised. The relation is, as stated above, one of authorship. The result of agency being known and taken for granted, there is a tendency to use imperfective, non-prefixed verbs in this subtype of the construction. This is why we have veidots rather than izveidots in (43). Similar examples in the corpus material include vāciešu tulkots 'translated by the Germans' (instead of pār-tulkots), intuīcijas raisīts 'induced by intuition' (instead of iz-raisīts), vāciešu celts 'built by the Germans' (instead of $u z$-celts) etc.

But we also find examples where agency, and the change of state it produces in the object, are not presupposed but asserted: 
(44) Latvian (lvTenTen)

Kamoliņ̌

ir

kožu

saēsts.

yarn.roll.NOM.sG

be.PRS.3

moth.GEN.PL

PFX.eat.PPP.NOM.SG.M

'The yarn roll is moth-eaten.'

Semantically, this is an instance of a resultative (stative) passive: ${ }^{16}$ a change of state in the object resulting from earlier agency is referred to; note that in this case the verb is perfectivised by the prefix $s a-$. See also such examples from the corpus material as rūsas saēsts 'rust-eaten', suña sakosts 'bitten by a dog', bebra aizgrauzts 'chewed at by a beaver'. However, the occurrence of an agent phrase is unexpected. Let us recall that an agent phrase cannot be added in a dynamic passive (the distinguishing feature of which is that it takes tikt 'become' rather than $b \bar{u} t$ 'be' as an auxiliary):

(45) Latvian

${ }^{*}$ Kamoliņs

tika

kožu

yarn.roll.NOM.SG

become.PST.3

moth.GEN.PL

saēsts.

PFX.eat.PPP.NOM.SG.M

Intended meaning: 'The yarn-roll was eaten by moths.'

At first glance, this would mean that an agent phrase can be added in the resultative passive but not in the dynamic passive. This, however, is unexpected, because it is known that there are severe restrictions on the occurrence of agent phrases in the resultative passive (cf. Vaagland 1983 for German), because it focuses on the state of the object, and the state of the object usually does not depend on the identity of the agent. This is why, in English, (46) can be interpreted both as a dynamic or as a stative/resultative passive (opposed to the door was open) while (47) can be interpreted only as a dynamic passive (opposed to the door was opened):

(46) The door was closed.

(47) The door was closed by fohn.

While there will always be exceptions to the general principle that stative passive contain no agent phrases (we will deal with them below),

${ }^{16}$ We assume that the resultative passive is a voice construction available at least in a number of languages, including German and Latvian. Many authors have proposed to interpret it as a copular construction with an adjectivised participle, but the construction has a number of clearly verbal features (like compatibility with adverbial modifiers); for German cf. Maienborn (2007) for a discussion, with an overview of the literature. 
we would not expect a language to have an agented resultative passive opposed to a systematically agentless dynamic passive. The conclusion we can draw from this is that the existence of sentences like (44) is probably due to the existence of a predicative agentive construction with basically the same structure, viz. the verb 'be' and a past passive participle. There is therefore an interaction between the agentive construction and the resultative passive in the sense that under specific conditions the resultative passive has acquired the ability of including agent phrases, borrowed from the agentive construction, or, looking at it from the other side, the agentive construction has extended into the domain of the resultative passive.

However, as already mentioned, the typical resultative passive is agentless, so the agentive construction could only extend to those situations where there is a particular reason for using an agent phrase in the resultative passive. One is a situation in which the character of the agent determines or crucially influences the nature of the change of state in the object. For example, being eaten by a moth is something different from being eaten by a human being. ${ }^{17}$ Therefore 'eaten by moths' or 'moth-eaten' is an agented construction fit to be used as a resultative passive. The agent is, in this type, always generic; in English, it is often incorporated, cf. worm-eaten, frost-bitten etc.

However, there are also situations where an individuated, non-generic agent can be used in the resultative passive because the type of affectedness of the object depends on the identity of an agent uniquely qualified to perform an action:

(48) Latvian (lvTenTen)

[Savukārt pārējo topošās koalīcijas partiju pārstāvji teikuši, ka viņiem nav iebildumu pret Pabrika kandidatūru gadījumā,]

ja kandidāts būs prezidenta

if candidate.NOM.SG be.FUT.3 president.GEN.sG

nominèts.

nominate.PPP.NOM.SG.M

'[In their turn, the representatives of the other parties of the prospective coalition have reportedly declared having no objections to Pabrik's candidacy] if the candidate is nominated by the President.'

${ }^{17}$ As Wayles Browne kindly pointed out to me, the difference would not be obvious in a passive construction: The yarn was eaten by moths would imply that it no longer exists; The yarn is moth-eaten, on the other hand, implies that only small parts of it are missing. 
Various factors may determine the relevance of the identification of the agent, and we will not attempt to give an exhaustive overview; both the lexical features of the verbs and the contexts in which it is used probably play a role here. Among the examples of this type in the corpus material there are kritiķu atzìts 'acknowledged by critics', notāra apstiprināts 'certified by a solicitor', etc. At this stage we only want to point out that there is a type of constructions containing agents but otherwise quite close to the resultative passive. However, as an agented resultative passive standing alongside a systematically agentless dynamic passive is somewhat of an incongruity, we will treat these constructions as belonging to the agentive construction, which allows us neatly to set apart the agentive construction and the resultative (stative) passive: while the former by definition contains an agent phrase, the second never does. It is obvious, however, that there has been a certain interaction between the two constructions.

We can also single out a large group of verbs implying neither creation nor indeed any form of agency. An example would be (49):

(49) Latvian (lvTenTen14)

\begin{tabular}{|c|c|c|c|c|}
\hline Saullēktos & Viestu & dārzs & ir & gaismas \\
\hline sunrise.LOC.PL & PLN.NC & & be.PRs.3 & light.gEN \\
\hline pieliets & & un & putnu & dziesmu \\
\hline $\begin{array}{l}\text { suffuse.PPP.N } \\
\text { pieskandināts }\end{array}$ & SG.M & and & bird.GEN.PL & song.GE N.PL \\
\hline
\end{tabular}

make.resound.PPP.NOM.SG.M

'At sunrise the Viesturs park is suffused with light and resounds with the singing of birds.'

See also similar examples ļaužu piepildìts 'crowded (literally: filled) with people', sniega pārklāts 'covered with snow', žoga iejozts 'encircled by a fence', dolomita nosēts 'formed by dolomite rock'. It is easy to see that gaismas in (49) is not an agent but a theme: the space of the park is filled with light and with the song of birds. In itself, the verb pieliet can take an agentive subject - referring to a person filling a vessel with a liquid, and such an agent is implied (though not expressed) in (50):

(50) Latvian (constructed)

$\begin{array}{lllll}\text { Kanna } & \text { bija } & \text { pielieta } & \text { ar } & \text { pienu. } \\ \text { jug.NOM.SG } & \text { be.PST.3 } & \text { pour.full.PPP.NOM.SG.F } & \text { with } & \text { milk.ACC.sG }\end{array}$

'The jug was poured full with milk.' 
To understand why the theme can occupy the position normally reserved for an agent in constructions like (49) we must invoke the notion of 'surface-impact verbs' introduced by Fillmore (1970). Surface-impact verbs are opposed to change-of-state verbs like 'break'. They describe the establishment or existence of contact between an impacting object or medium (theme) and an impacted object (patient), brought about by an external causer (often a natural force). In constructions with surface-impact verbs, the theme can take over the subject position from the causer when the latter is not expressed, a process we could characterise as 'causer-theme conflation'. In the case of change-of-state predicates, this has an analogue in the form of 'agent-instrument conflation' ('Instrument Subject Alternation' in Levin's classification, cf. Levin 1993, 80). Compare:

(51) The boy broke the window with a stone.

(52) The stone broke the window.

(53) The boy hit the window with a stone.

(54) The stone hit the window.

There is, however, as Fillmore points out, an important difference in syntactic behaviour between the two classes of verbs, viz. in the derivation of intransitive uses:

(55) The window broke.

(56) *The window hit.

The ungrammaticality of (56) results from the fact that while a changeof-state predicate can underlie a one-place predication (the window broke), a surface-impact verb cannot: it can only denote a surface impact (or simply contact or contiguity) between two objects, and can therefore only underlie at least two-place predications. A result of this is that while (57) is a complete sentence, $\left(5^{8}\right)$ is not: it requires the addition of a theme argument.

(57) The glass is broken.

(58) *The park is suffused.

Surface-impact verbs are basically atelic, as they do not describe a change of state in the object of impact that could 'measure out' the action. There are, however, exceptions to this rule: some surface-impact verbs have a holistic implication, i.e. they denote a situation in which contact is established with the whole of the object of impact, as cover (holistic affectedness of an outer surface), fill (holistic affectedness of an inner surface or space) and 
surround (holistic affectedness of a circumference or surrounding space). In example (49), the prefix pie- introduces the holistic meaning 'suffuse completely with light', 'fill completely with sound'. The verb pieliet, used in (49), shows the twofold pattern mentioned above, with expressed causer and with causer-theme conflation ('Locatum Subject Alternation' in Levin's classification, cf. Levin 1993, 81), cf. (59) and (6o):
(59) $[\ldots]$ saule
pielej ร̌o
brīnumaino
sun.NOM.SG suffuse.PRS.3 DEM.ACC.SG
miraculous.ACC.SG.DEF
dārzu

ar
spožu
gaismu....
garden.ACC.SG
with
bright.ACC.SG
light.ACC.SG
'the sun suffuses this miraculous garden with bright light ${ }^{\text {'18 }}$
(6o) Spoža$$
\text { pēcpusdienas }
$$
saule
bright.NOM.SG.F afternoon.GEN.SG
sun.NOM.SG
pielēja
suffuse.PST.3
plavas,
celı $u$
un
sasildīja
meadow.ACc.PL road.ACc.sG and warm.PST.3 traveller.ACC.PL
'A bright afternoon sun suffused the meadows and the road and warmed the travellers.' ${ }^{19}$

It is the variety in (6o) that can be invoked to explain the appearance of the theme in agent position in the agentive construction. However, the occurrence of themes in the agent phrase position is not limited to verbs that allow causer-theme conflation. Some noun phrases occupying the agent position in the agentive construction cannot occur as subjects in the corresponding active construction. Here we use examples from the adnominal agentive construction. Example (61) is from older literature, while (62) is from the modern language:

(61) Latvian (Rūdolfs Blaumanis, 1863-1908, Velniņi)

[Aiz vārtiem otrs burlaka gaidīja, gaidīja, piekusa pēdīgi stāvēdams]

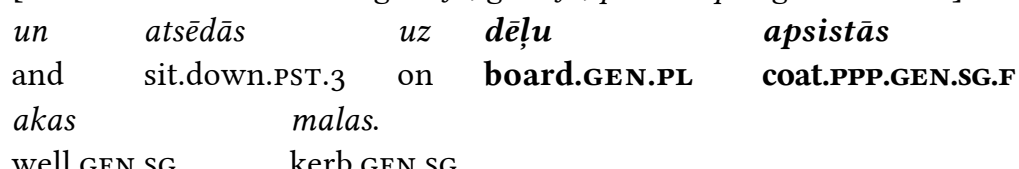

well.GEN.SG kerb.GEN.SG

'[Outside the gate the other barge-hauler waited till he got tired standing] and sat himself down on the board-coated kerb of the well.'

\footnotetext{
${ }^{18}$ https://ceitaspasaule.blogspot.com/2010/10/mans-saulainais-darzs.html

${ }^{19}$ https://www.gandrs.lv/atputa/atskati/lielas-juglas-kangara-apavi-27-februaris/
} 
(62) Latvian (LVK2013)

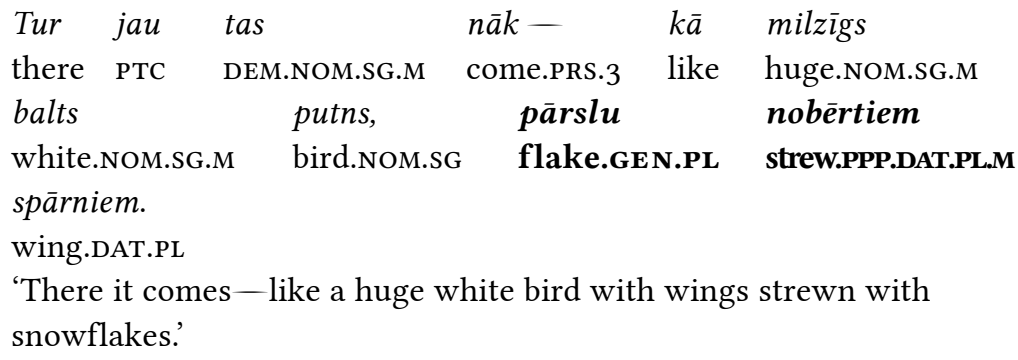

With these verbs there are no corresponding constructions in which the theme occupies the subject position:
(63) * Dēḷ
apsit
akas
malu.
board.NOM.SG
coat.PRS.3 well.GEN.SG
kerb.ACc.sG
intended meaning: 'Boards coat the kerb of the well.'

Such instances as (61), (62) are certainly rare and apparently characteristic of literary usage. The more usual constructions have instrumental marking (with the instrumental-comitative preposition ar 'with') for the theme:

(64) Latvian (LLVV s.v. apsist)

\begin{tabular}{|c|c|c|c|c|}
\hline $\begin{array}{l}\text {.. vinga } \\
\text { 3.NOM.SG.F }\end{array}$ & $\begin{array}{l}\text { paverra } \\
\text { half.open.PST.3 }\end{array}$ & $\begin{array}{l}a r \\
\text { with }\end{array}$ & $\begin{array}{l}\text { brūnu } \\
\text { brown.AcC.sG }\end{array}$ & $\begin{array}{l}\bar{a} d u \\
\text { leather.ACC.SG }\end{array}$ \\
\hline apsistās & $d u r v$ & & & \\
\hline coat.PPP.AC & C.F.DEF & ].ACC & & \\
\hline
\end{tabular}

Though rare, constructions with the genitive that do not have corresponding constructions with causer-theme conflation as illustrated above for pieliet might perhaps be viewed as evidence that the agentive construction with a theme in agent position need not necessarily be motivated or conditioned by the construction with causer-theme conflation, even though it stands to reason that constructions with causer-theme conflation have played a crucial role in the spread of the agentive constructions to semantic role frames consisting of just theme and object-of-impact, without agent involved. Presumably there is a kind of distinct rule saying that in the agentive construction the agent phrase may be a theme if the verb belongs to the class of surface-impact predicates.

The construction with causer-theme conflation does not imply agency, though one could argue it presents the event as having occurred due to a natural force given the same grammatical status as a wilful and sentient 
agent which has the ability to pour light into a space referred to like liquid in a vessel. For all practical purposes, however, a construction as in (49) refers to a spatial configuration involving theme and impacted object. ${ }^{20}$ In such constructions denoting a spatial configuration not thought of as resulting from previous agency there is an obligatory theme argument that, in many languages, can receive instrumental marking (the plot is surrounded with trees) but may also be shaped as an agent phrase (the plot is surrounded by trees). Of course, even if agent phrase encoding is chosen, the $b y$-phrase is not an agent but a theme.

The construction in (49) seems to be a further development from the resultative construction in (44). Its similarity to the resultative construction consists in that it refers to a state of an object, which the agentive construction does not. This state is specified as a spatial relation with regard to another object, but the use of the past passive participle suggests that this state is represented as resulting from a previous event. In this case, the event is not a change-of-state but a holistic surface-impact event resulting in a new spatial situation of the object-of-impact.

The predicative agentive construction based on surface-impact verbs presents us with a scale based on the degree of metaphorisation. Some surface-impact verbs refer to a spatial configuration:

(65) Latvian (lvTenTen14)

Ja Krievija patiesi būtu tik loti naidnieku
if Russia.Nom truly be.IRR so very enemy.GEN.PL
ielenkta,
surround.PPP.NOM.sG.F
[tad viņi to galu galā būtu iekarojuši].
'If Russia had really been so utterly surrounded by enemies,
[they would have conquered it in the end.]'

Others refer to emotive states and involve spatial conceptualisation of emotions. The latter are viewed as substances that can fill out an experiencer's mental space, pervade (that is, flow through) it, weigh upon it from above etc.

\footnotetext{
${ }^{20}$ The same holds for anticausatives derived from surface-impact verbs, as argued in Holvoet (2018). Transitive verbs denoting causation of a change of state form the basis of one-place anticausatives (the sun melted the snow : the snow melted) whereas those denoting causation of surface impact derive two-place anticausatives (the sun filled the room with light: the room filled with light).
} 
(66) Latvian (lvTenTen14)

fo organismā, kurš ir labsajūtas

for organism.LOC.SG REL.NOM.SG.M be.PRS.3 well-being.GEN.SG

apnemts,

envelop.PPP.NOM.SG.M

[retāk iemājo baktērijas un vīrusi, arī sēnītes.]

'For in an organism that is enveloped by well-being, [bacteria, viruses and fungi do not so frequently take hold.]'

(67) Latvian (lvTenTen14)

Pavaditais vakars bija

spend.PPP.NOM.SG.M.DEF evening.NOM.SG be.PST.3

sirsnibas un jauku atmiņu

cordiality.GEN.SG and nice.GEN.PL recollection.GEN.PL

caurstrāvots.

pervade.PPP.NOM.SG.M

'The evening spent [together] was filled with cordiality and agreeable recollections.'

Other examples in the corpus include sajūsmas uzlādèts 'loaded with enthusiasm', ironijas piesātināts 'saturated with irony' etc. Finally, we must discuss a type of constructions with agent phrases which cannot be qualified as resultative because the participle does not denote a change of state, but there is also no surface impact situation. This is the type:

(68) Latvian (lvTenTen14)

[fa tu esi pieaudzis cilvēks, tad tev pašam ir savas personīgas attiecības ar Debesu Tèvu],

\begin{tabular}{lllll} 
un & $t u$ & esi & Dieva & vadīts, \\
and & 2SG.NOM be.PRS.2SG & God.GEN.sG & lead.PPP.NOM.SG.M \\
nevis & mācìtāja & vai & mājas & grupas \\
not & priest.GEN.SG or & house.GEN.SG & group.GEN.SG \\
lìdera & \multicolumn{2}{c}{ vadits. } & &
\end{tabular}

leader.gen.sg lead.PPP.NOM.sg.m

'[If you are a grown-up person, then you have a personal relationship with the Heavenly Father,] and you are led by God, (you are) not led by a priest or a leader of your home group.'

Other instances include valsts finansēts 'funded by the state', pašvaldības algots 'paid by the municipality', mācìtāja pārraudzìts 'monitored by a priest', etc. The example in (68) is interesting in that the verb vadit is atelic: it is 
a caused-motion predicate implying continuous control, not culminating causation leading to a new state. But we could not translate (68) as 'you are being led by God' because that would be a dynamic passive, which, in principle, is agentless. In order to explain (68) we will introduce an extended notion of authorship. Authorship basically presupposed previous agency, but it is a relation extending beyond the moment of completion of this agency: there is a relationship between author and book subsisting after the book was completed. In a number of situations, this relationship can probably be interpreted as one of authority, e.g., 'appointed by the King' or 'founded by the Government' can mean that the subject is accountable to, dependent on the appointer, founder etc. We will call this a relation of authority.

A similar extension of the notion of authorship, but applying to inanimates, is the causal relationship. Like the relationships of authorship and authority, it extends in time beyond the time of agency proper: a situation A produces a situation $\mathrm{B}$ at a specific time but the causal relationship established between the two remains valid.

We can now propose a tentative schema meant to show the different extensions of the agentive construction. It is not intended as a semantic map though it might serve as a basis for one. It comprises three clusters - agentive, agentive-resultative and surface-impact.

Figure 1. Semanticsubtypes of the agentive construction in Latvian

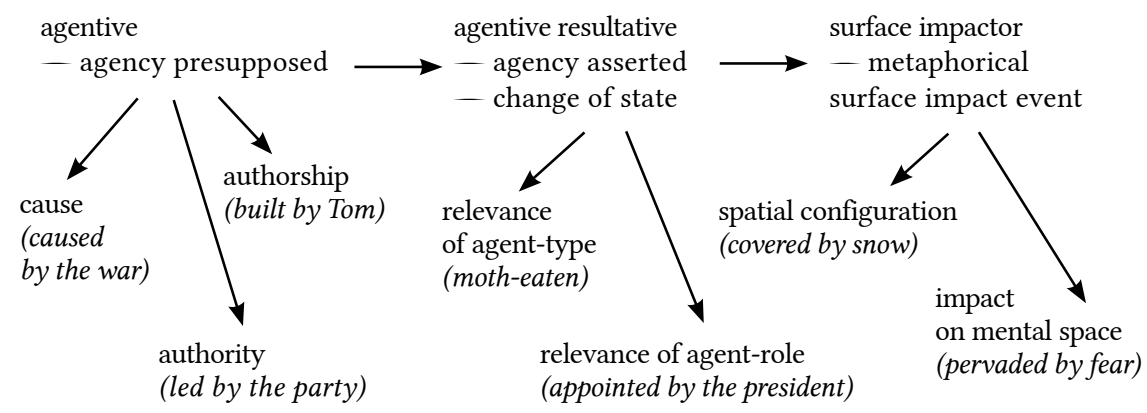




\section{A comparative glance at the Finnish agentive construction}

We have not carried out an independent corpus investigation of the Finnish agentive construction, but we have checked whether the types of agentive constructions singled out in Latvian have counterparts in the Finnish material. The answer to this question was mostly in the affirmative. Apart from the agentive construction proper, illustrated above, we can find constructions in which the relation of authorship is replaced by that of authority. The whole construction does not specify a state of the subject (the original object of the transitive verb) but refers only to the relationship of authority:

(61) Finnish (Korp)

$\begin{array}{llll}\text { Syrjintä } & \text { oli } & \text { myös } & \text { virallisesti } \\ \text { discrimination.NOM } & \text { be.PST.3SG also } & \text { officially } \\ \text { valtion } & \text { tuke-ma. } & & \\ \text { state.GEN.SG } & \text { support-AGP[NOM] } & \end{array}$

'Discrimination was also officially supported by the state.'

And we also find a closely related construction with inanimate genitives, denoting a causal relationship rather than one of authority:

(62) Finnish (Korp)

$\begin{array}{llll}\text { Elintarvikepula } & \text { oli } & \text { sodan } & \text { aiheutta-ma. } \\ \text { food.shortage.NOM } & \text { be.PST.3SG } & \text { war.GEN.SG } & \text { cause-AGP[NOM] }\end{array}$

'The food shortage was caused by the war.'

The agentive-resultative subtype, in which agency is no longer presupposed but asserted, and a resultant state of the subject (the original object) is described, is also represented:

(63) Finnish

$\begin{array}{llll}\text { Hattu-ni } & \text { on } & \text { koiden } & \text { syö-mä. } \\ \text { hat.NOM-1SG } & \text { be.PRS.3SG } & \text { moth.GEN.PL } & \text { eat-AGP }\end{array}$

'My hat is eaten by moths.'

Finally, we find the surface-impact type in its purely spatial variety:

(64) Finnish (Korp)

\begin{tabular}{|c|c|c|c|}
\hline $\begin{array}{l}\text { Puutarha } \\
\text { garden.NOM.SG }\end{array}$ & $\begin{array}{l}\text { on } \\
\text { be.PRS.3SG }\end{array}$ & $\begin{array}{l}\text { puuston } \\
\text { trees.GEN.SG }\end{array}$ & $\begin{array}{l}\text { ympäröi-mä. } \\
\text { surround-AGP }\end{array}$ \\
\hline
\end{tabular}


It should be noted that the Finnish agentive participle does not by itself denote a state of an object resulting from a previous change of state, as the Latvian past passive participle does. The agentive-resultative subtype is therefore an internal semantic development of the agentive construction, not the result of contamination of the agentive construction with the resultative passive.

It seems that both for Finnish and for Latvian we may reconstruct successive semantic shifts: prototypical agentive construction $\rightarrow$ agentive resultative construction $\rightarrow$ surface impactor (spatial configuration).

\section{The Lithuanian agented passive}

After our discussion of Latvian and Finnish, two languages with an agentive construction, we will look at Lithuanian, which has developed an agented passive out of an agentive construction. Our aim is to see what has changed in the domain of the expression of the agent.

Lithuanian has an adnominal passive construction based on both present and past passive participles: $:^{21}$

(65) Lithuanian

graiku statomas miestas

Greek.GEN.PL build.PPRP.NOM.SG.M city.NOM.SG

' $\mathrm{a}$ /the city that is being built by the Greeks'

(66) graiku pastatytas miestas

Greek.GEN.PL build.PPP.NOM.SG.M city.NOM.SG

'a/the city built by the Greeks'

Moreover, as mentioned above, Lithuanian also has an agentive sentential passive. It can also be based either on the present or on the past passive participle:

(67) Lithuanian

Miestas yra graiku statomas.

city.NOM.sG be.PRS.3 Greek.GEN.PL build.PPRP.NOM.SG.M

'A/the city is being built by the Greeks.'

${ }^{21}$ The difference between present and past passive participles is partly temporal, partly aspectual. Passives with present past participles have a dynamic (actional) meaning, while passives with past passive participles may have both dynamic and stative resultative meaning, cf. namas (yra) statomas 'the house is being built' vs namas (yra) pastatytas 'the house is/has been built'. 

(68) Miestas
buvo
graiku
pastatytas.
city.NOM.SG be.PRS.3 Greek.GEN.PL build.PPP.NOM.SG.M
'A/the city was built by the Greeks.'

Although the predicative agentive construction no longer exists in Lithuanian as it was absorbed by the agented passive, the Lithuanian passive still bears some traces of the source construction. Firstly, it is mentioned in the literature that overt expression of the agent in Lithuanian passives is dispreferred and that agentive passives are rather infrequent (Jakuliene 1968, 212). Agented passives account for only $6.5 \%^{22}$ out of 5,245 passive constructions in Geniušienè's sample (Geniušienè 2016, 146). For the sake of comparison, the reported frequency of agented passives in other languages is, e.g., 18.3\% for English (Fredriksson 2016, 75), 12.5\% for Swedish, $12.6 \%$ for Danish and 9.3\% for Norwegian (Laanemets 2012, 125). Thus, the agented passive is about 2 times less frequent in Lithuanian than in some Germanic languages.

Secondly, though the genitive of the agent was extracted from the participial constituent of the agentive construction and became a clausal constituent, which manifests itself in its ability to occur clause-finally, overt agents in Lithuanian passives still predominantly occur in preverbal position (in $59 \%$ of the cases) (Geniušienè 2016, 102), cf. (69):

(69) Lithuanian (Geniušienè 2016, 103).

[Vienintelè jos duktė Onutè, ištekëjusi už nenuoramos student Bartku fono,]

$\begin{array}{lcll}\text { kuris } & \text { smetoninès } & \text { policijos } & \text { buvo } \\ \text { REL.NOM.SG.M } & \text { Smetona.ADJ.GEN.SG.F } & \text { police.GEN.SG } & \text { be.PST.3 } \\ \text { ištremtas } & i \quad \text { šiuos } & \text { kraštus, } & \\ \text { exile.PPP.NOM.SG.M } & \text { to } \text { DEM.ACC.PL.M } & \text { land.ACC.PL } & \end{array}$

[išvažiavo kažkur...]

'[Her only daughter Onute, having got married to the restless student Jonas Bartkus], who had been deported to this region by Smetona's police, moved to some other place...'

Interestingly, in $75 \%$ of the examples with the word order pattern 'subject + oblique agent + predicate', the agent is human (Geniušienè 2016, 102), which might also be a reminiscence of the agentive construction, which had, in the prototypical case, a human agent.

\footnotetext{
${ }^{22}$ This figure includes evidentials of verbs other than $b \bar{u} t i$ 'be', which we have argued are not passive constructions. Without evidentials, the percentage would be smaller.
} 
The second most common word order pattern in agented passives (32\% of the cases), according to Geniušiene (ibid.), is that with post-verbal, clause-final agents. The author points out that in passive constructions of this type, the agent is more likely to be non-human (in $65 \%$ of the cases) while the subject tends to be human (ibid., 104). According to Geniušienè, most personal agentive passives with non-human agents are based on desemanticised verbs realising two different lexical functions Func 1 and Func2. The notion of lexical functions is taken from Mel'čuk and Žolkovskij's Meaning-Text Theory (Žolkovskij \& Mel'čuk 1967). Geniušienè writes:

'In such constructions the main semantic load is borne by the agent, with the verb bleached of its semantics and functioning in a way similar to a copula. The agent is semantically obligatory and cannot be omitted' (Geniušienè 2016, 76).

An example provided by Geniušiene for such a construction is reproduced in (70):

(70) Lithuanian (from Geniušienè 2016, 77)

$\begin{array}{llll}\text { Elze } & \text { buvo } & \text { apnikta } & \text { nevilties. } \\ \text { PN.NOM.SG } & \text { be.PST.3 } & \text { beset.PPP.NOM.SG.F } & \text { desperation.GEN }\end{array}$

'Elzè was beset by desperation.'

Geniušiene's point is that apnikti does not have a very precise lexical meaning here: in fact, one could replace apnikta nevilties with apimta nevilties 'enveloped by despair' and the meaning would not fundamentally change, both verbs being idiomatic realisations of a lexical function that could be formulated as 'experience (the emotion denoted by the noun)'. The semantic emptiness of the verb would explain the obligatory character of the agent phrase.

However, Geniušienè's account is, in many cases, not quite satisfactory. It is hard to believe that būti užverstam 'be covered, buried under' and būti apsuptam 'be surrounded' are realisations of the same lexical function (as suggested by Geniušienè 2016, 158), considering that both have very precise meanings referring to completely different spatial configurations. In fact, verbs referring to such spatial configurations have already been mentioned above in the context of the Latvian predicative agentive construction, and we will return to this below. Secondly, Geniušienè's characterisation of the genitival NP as an agent in all constructions with the supposedly bleached verbs is not convincing. 
We propose, therefore, an alternative account invoking the notion of surface-impact verbs that has proved useful in characterising the Latvian predicative agentive construction. We will discuss the following subtypes: (1) verbs of physical impact, (2) verbs of emotional impact, and (3) other.

It is easy to notice that many of the verbs listed as functional by Geniušienè are in fact holistic surface impact verbs, e.g. užversti 'cover, bury under', uždengti 'cover', apsupti 'surround', nutvieksti 'suffuse (with light)', užlieti 'bathe, suffuse (with light)'. An example with $u z ̌ v e r s t i$ 'cover, bury under' is given in (71):

(71) Lithuanian

Užklupus

catch.unawares.ANT.CVB

gausiam sniegui,

Anykščiu miesto

abundant.DAT.SG.M snow.DAT.SG

PLN[PL].GEN town.GEN.SG street.NOM.PL bury.under.PPP.NOM.PL.F

sniego.

snOW.GEN.SG

'After this unexpected abundant snowfall, the streets of Anykščiai are buried under snow. ${ }^{23}$

The genitival argument sniego in (71) is not an agent but a theme, as is confirmed by the possibility of marking the same argument with the instrumental:

(72) Lithuanian

Iš pradžiu jos buvo užverstos

at.first 3.NOM.PL.F be.PST.3 bury.under.PPP.NOM.PL.F

sniegu.

snow.INS.SG

'At first they [sc. the streets] were buried under snow. ${ }^{24}$

The instrumental marking is in fact more common than the genitive with $u \check{z}$ versti. As in the case of Latvian, the genitival marking may be at least partly motivated by a construction with causer-medium conflation, characteristic of surface impact verbs. The medium (theme) is assigned subject position, cf.:

\footnotetext{
${ }^{23}$ http://m.anyksta.lt/naujienos/naujienos/62727-sniego-vezimas-pakazucha?reply_to=451204

${ }^{24}$ http://www.diena.lt/naujienos/lietuva/salies-pulsas/kasmete-pasaulio-pabaiga-455727
} 
(73) Lithuanian

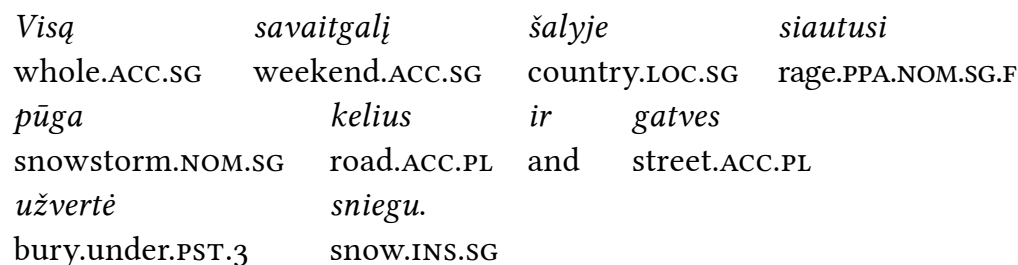

'The snowstorm raging the whole weekend in the country buried the roads and streets under snow. ${ }^{25}$

(74) Lithuanian (CCLL)

$\begin{array}{lccc}\text { smarkiai } & \text { prisnigo, } & \text { sniegas } & \text { užverte } \\ \text { heavily } & \text { snow.PST.3 } & \text { snow.NOM.SG } & \text { cover.PST.3 } \\ \text { gatves, } & \text { sustabde } & \text { transporta. } \\ \text { street.NOM.PL } & \text { disrupt.PST.3 } & \text { transport.ACC.SG }\end{array}$

'It snowed heavily, the snow covered the streets, disrupted the transport.'

A slightly different situation is observed with nutvieksti 'suffuse (of light)'. Both in the predicative and in the adnominal agentive construction the agent or theme argument always receives genitival marking, and in the corresponding active construction the theme (medium) is always the subject. In other words, causer-medium conflation is obligatory here:

(75) Lithuanian

menesienos nutviekstas dangus

moonlight.GEN.SG suffuse.PPP.NOM.SG.M sky.NOM.SG

'a/the sky suffused with moonlight' ${ }^{\prime 26}$

(76) Lithuanian

Spindinti menesienos šviesa nutvieskè

shining.NOM.SG.F moonlight.GEN.SG light.NOM.SG suffuse.PST.3

rugpjūčio nakties dangų.

August.gen.sg night.gen.sg sky.ACC.sG

'The radiant light of the moon suffused the nocturnal August sky.' ${ }^{27}$

This brings us to a third group of verbs comprising nugairinti 'weather (of the effect of sun or wind)', and nušiurinti 'fray'. Two things are remarkable

\footnotetext{
${ }^{25}$ https://www.tv3.lt/naujiena/lietuva/705226/spaudos-apzvalga-salyje-siautusi-puga-snieguuzverte-kelius-ir-gatves

${ }^{26}$ http://azijoszinynas.vdu.lt/kinija-taivanas/tibeto-mirusiuju-knyga-2/

${ }^{27}$ https://www.efoto.lt/user/36633/www/geriausios?page $=3 \&$ view=all
} 
about them: they denote a change in state, and they contain derivational suffixes normally deriving causatives from non-causative verbs, as in sušlapti 'get wet' $\rightarrow$ sušlapinti 'wet'. This would suggest that their subjects must be causers rather than themes, so that they call for an explanation different from that offered above for surface-impact verbs. The English counterparts with incorporation, such as sun-tanned and wind-frayed, suggest this could be an instance of reference to a type of causer, as in Latvian kožu saēsts 'moth-eaten' in (44) above. However, the word-order model in (78) below is more characteristic of constructions derived from surface-impact verbs, so that it is ultimately unclear by which subtype of the resultative passive the constructions with nugairinti and nušiurinti are motivated.

(77) Lithuanian

$\begin{array}{llclll}\text { Geriau } & \text { pažiūrékime } & \dot{q} & \text { veidrodi } & \text { ir } & \text { pamatysime, } \\ \text { better } & \text { look.IMP.1PL } & \text { at } & \text { mirror.ACC.SG and } & \text { see.FUT.PL2 } \\ \text { kad } & \text { saule } & \text { jau } & \text { gerokai nugairino } & \text { veida } \\ \text { that } & \text { sun.NOM.SG } & \text { already } & \text { rather } & \text { burn.PST.3 } & \text { face.ACC.SG }\end{array}$

'Let us look closer at the mirror and we will see that the sun has already burnt our faces considerably ${ }^{28}$

(78) Lithuanian (CCLL)

fo veidas buvo nugairintas

his face.NOM.sG be.PST.3 sun.beaten.PPP.NOM.SG.M

pajūrio saules.

sea.side.GEN.SG

sun.GEN.SG

'His face was tanned by the seaside sun.'

Another group of verbs forming resultative passives with obligatory non-human agents denotes emotional (and mental) states, cf. apnikti 'beset', iškankinti 'torture, torment', prislègti 'depress, oppress', apimti 'envelop', persmelkti 'pervade', iškreipti (veida) 'distort (face)'. Semantically, they are close to holistic surface impact verbs in that they denote emotional states that fill, pervade, or envelop the whole person. Cf. ex. (79) and (80):

(79) Lithuanian (Geniušienè 2016, 77)

$\begin{array}{lll}\text { Neviltis } & \text { apniko } & \text { Elzę. } \\ \text { desperation.NOM.SG } & \text { beset.PST.3 } & \text { PN.ACC.SG } \\ \text { 'Desperation beset Elzè.' } & \end{array}$

\footnotetext{
${ }^{28} \mathrm{http} / / /$ www.respublika.lt/lt/naujienos/lietuva/kitos_lietuvos_zinios/kai_pavasario_lieka_ nedaug/,print.1
} 
(8o) Elzè

buvo

apnikta

nevilties.

PN.NOM.SG

be.PST.3

beset.PPP.NOM.SG.F

desperation.GEN

'Elzè was beset by desperation.'

Nouns denoting emotional states, such as neviltis 'desperation', liūdesys 'sadness', sielvartas 'sorrow' etc. are not true agents; they can be interpreted as theme-arguments. For this reason, we can consider these verbs as a metaphorical extension of holistic surface impact verbs.

(81) Lithuanian (CCLL)

\begin{tabular}{|c|c|c|c|}
\hline Visada & būdavo & apniktas & nusivylimu \\
\hline $\begin{array}{l}\text { always } \\
\text { ir }\end{array}$ & $\begin{array}{l}\text { be.HAB.PST.3 } \\
\text { abejoniu. }\end{array}$ & beset.PPP.NOM.SG.M & disappointment.GEN.PL \\
\hline
\end{tabular}

'He was always beset by disappointments and doubts.'

The last group comprises several verbal lexemes mentioned as 'functional' by Geniušiene that do not fit into the first two groups for semantic reasons, namely lemti 'cause', salygoti 'condition' and jungti 'unite, connect'. Their place on the semantic map of Lithuanian stative-resultative constructions is not clear: they express a causative relationship and thereby show a certain affinity with properly agentive predicates, but their subjects are always inanimate, as in the surface-impact type.

The behaviour of Lithuanian stative-resultative passives with regard to the presence of agent phrases is, as we have seen, highly reminiscent of the situation with the predicative agentive construction in Latvian. It is obvious, however, that Lithuanian has no distinct agentive construction any more, as it was absorbed by the agented passive. The two varieties of the predicative agentive construction, still discernible in Latvian, underwent a different fate. The properly agentive variety, prototypically with change-of-state verbs, was absorbed by the agented dynamic passive, whereas the variety with surface-impact verbs became a subtype of the stative-resultative passive.

\section{In conclusion}

In this article we have looked at the agentive construction, a minor construction type primarily denoting authorship of an object but also extending to the adnominal and predicative expression of relations of agency, authority, 
cause and contiguity. It is functionally related to the resultative passive in that both constructions are patient-oriented predicative or attributive types of expressions. The difference between the two lies in that the agentive construction highlights the relationship to the agent whereas the resultative passive tends to abstract away from the agent. Nevertheless, there is a certain overlap between the two.

Apart from their theoretical relevance, the constructions dealt with in this article are also of areal-typological interest. The existence of agentive constructions that are not part of an agented passive, and the genitival encoding of the agent, constitute an areal convergence between Fennic and Baltic. Possessive encoding of the agent is not uncommon typologically (it is among the major types mentioned by Keenan \& Dryer 2007, 344), but the fact that Baltic adopted this strategy in harmony with Fennic is not devoid of interest and has been discussed in the literature (cf. most recently de Smit 2015). More specifically one cannot help being struck by the FennicLatvian convergence: for many centuries, Latvian, which has the closest areal links with Fennic and partly developed on a Fennic substratum, had an agentive construction not evolving into a passive, whereas Lithuanian has carried over the genitival marking of the agent in agentive constructions to the passive proper.

\section{AbBreviations}

ACC - accusative, ADJ - adjectival suffix, AGP - agentive participle, ANT - anterior, CVB - converb, DAT - dative, DEF - definite, DEM - demonstrative, EVID - evidential, F - feminine, FUT - future, GEN - genitive, genposs - possessive genitive, HAB - habitual, IMP - imperative, INESS inessive, INS - instrumental, IRR - irrealis, LOC - locative, $\mathrm{M}$ - masculine, NEG - negation, NOM - nominative, PART - partitive, PASS - passive, PFX - prefix, PL - plural, PLN - place name, PN - personal name, PPA - past participle active, PPP - past passive participle, PPRP - present participle passive, PRS - present, PRTC - participle, PST - past, PTC - particle, Q - interrogative marker, REL - relative pronoun, RPOSS - reflexive possessive, SBJ - subject, SG - singular 


\section{SOURCES}

CCLL $=$ Corpus of the Contemporary Lithuanian Language at

http://tekstynas.vdu.lt

lvTenTen14 = Latvian Web Corpus at https://www.sketchengine.eu/lvtentenlatvian-corpus

LVK2013 = Balanced Corpus of Modern Latvian at http://www.korpuss.lv LLVV = Latviešu literārās valodas vārdnica [Dictionary of the Latvian Literary Language] at https://tezaurs.lv/llvv

Korp $=$ Finnish language corpus at https://korp.csc.fi

\section{REFERENCES}

Ambrazas, Vytautas. 2001. Lietuvių kalbos pasyvo raidos bruožai [Outline of the development of the Lithuanian passive]. Acta Linguistica Lithuanica 45, 11-38.

Ambrazas, Vytautas. 2006. Lietuviu kalbos istorine sintaksé [Lithuanian Historical Syntax]. Vilnius: Lietuvių kalbos institutas.

Ariste, PAul. 1968. A Grammar of the Votic Language (Indiana University Publications, Uralic and Altaic Series, 68). The Hague: Mouton.

Biber, Douglas et al. 1999. Longman Grammar of Spoken and Written English. Harlow: Pearson Education.

Blevins, James P. 2003. Passives and impersonals. fournal of Linguistics $39,473-520$.

BudiñA-LAZdiñA, TeRĒZA. 1966. Teach Yourself Latvian. London: The English Universities Press.

Chun, Soon Ae \& David A. Zubin. 1990. Experiential vs agentive constructions in Korean narrative. Berkeley Linguistics Society 16, 81-93.

Culy, Christopher. 1985. The complexity of the vocabulary of Bambara. Linguistics and Philosophy 8, 345-351.

Dahl, Östen. 1985. Tense and Aspect Systems. Oxford: Blackwell.

DE Smit, Merlijn. 2015. Agented participles in Baltic and Finnic. In: Santeri Junttila, ed., Contacts Between the Baltic and Finnic Languages (= Uralica Helsingiensia 7), 246-271. 
Endzelin, JAN. 1923. Lettische Grammatik. Heidelberg: Carl Winter.

Eroms, Hans-Werner. 200o. Syntax der deutschen Sprache. Berlin-New York: Walter de Gruyter.

Fillmore, Charles J. 1970. The grammar of hitting and breaking. In:

Roderick A. Jacobs \& Peter S. Rosenbaum, eds., Readings in English

Transformational Grammar. Waltham, MA: Ginn \& Co, 120-133.

FraEnKel, ERnst. 1928. Syntax der litauischen Kasus. Kaunas:

L. U. Humanitarinių Mokslų Fakultetas.

Fredriksson, AnnA-LenA. 2016. A Corpus-Based Contrastive Study of the Passive and Related Constructions in English and Swedish.

Doctoral dissertation, University of Gothenburg. https://gupea.ub.gu.se/ bitstream/2077/41822/1/gupea_2077_41822_1.pdf.

Geniušienė, Emma. 2016. Passive Constructions in Lithuanian. Selected Works of Emma Geniušienè. Edited by Anna Kibort \& Nijolè Maskaliūnienè. Amsterdam-Philadelphia: John Benjamins.

Hakulinen, Lauri. 1957, 1960. Handbuch der finnischen Sprache. 1-2. Wiesbaden: Otto Harrassowitz.

Holvoet, Axel. 2001. Impersonals and Passives in Baltic and Finnic. In: Östen Dahl \& Maria Koptjevskaja-Tamm, eds., The Circum-Baltic Languages: Typology and Contact. Vol. 2, Grammar and Typology, Amsterdam-Philadelphia: John Benjamins, 363-389.

Holvoet, Axel. 2007. Mood and Modality in Baltic. Kraków:

Wydawnictwo Uniwersytetu Jagiellońskiego.

Holvoet, Axel. 2018. On so-called converse reflexives in Slavic and Baltic, Zeitschrift für Slawistik 63.3, 373-394.

Huddleston, Rodney \& Geoffrey K. Pullum, eds., 2002. The Cambridge Grammar of the English Language. Cambridge: University Press.

JAKulienĖ, AudronĖ. 1968. Lietuvių kalbos pasyvo formavimasis ir sangrąžiniai veiksmažodžiai [Reflexive verbs and the formation of the Lithuanian passive]. Baltistica 4.2, 211-220.

Karlson, Fred. 2002. Finnish: An Essential Grammar. London-New York: Routledge.

Keenan, Edward L. \& Matthew S. Dryer. 2007. Passive in the world's languages. In: Timothy Shopen, ed., Language Typology and Syntactic Description. Vol. 1. Clause Structure. Cambridge: Cambridge University Press, 325-361. 
LAanemets, Anu. 2012. Passiv i moderne dansk, norsk og svensk. Et korpusbaseret studie af tale- og skriftsprog. Doctoral dissertation, University of Tartu. https://dspace.ut.ee/bitstream/handle/10062/27711/laanemets_ anu.pdf?sequence $=1$ \&isAllowed $=y$

LAVINE, JAMES E. 2006. Is there a passive evidential strategy in Lithuanian? Chicago Linguistic Society 42, 41-55.

Levin, Beth. 1993. English Verb Classes and Alternations: A Preliminary Investigation. Chicago-London: University of Chicago Press.

LinDSTRÖM, LIINA. 2015. Subjecthood of the agent argument in Estonian passive constructions. In: Marja-Liisa Hellasvuo \& Tuomas Huumo, eds., Subjects in Constructions - Canonical and Non-Canonical. AmsterdamPhiladelphia: John Benjamins, 141-173.

Maienborn, Claudia. 2007. Das Zustandspassiv. Zeitschrift für germanistische Linguistik 35, 83-114.

Malchukov, Andrej \& Anna Siewierska. 2011. Introduction. In: Andrej Malchukov \& Anna Siewierska, eds., Impersonal Constructions. A CrossLinguistic Perspective. Amsterdam-Philadelphia: John Benjamins, 1-15.

NAU, Nicole. 2016. Argument realization in Latvian action nominal constructions. A corpus-based investigation. In: Axel Holvoet \& Nicole Nau, eds., Argument Realization in Baltic, Amsterdam-Philadelphia: John Benjamins, 461-518.

Nau, Nicole \& Axel Holvoet. 2015. Voice in Baltic. An overview. In: Axel Holvoet \& Nicole Nau, eds., Voice and Argument Structure in Baltic, Amsterdam-Philadelphia: John Benjamins, 323-365.

Shagal, Ksenia. 2017. Towards a Typology of Participles. PhD thesis, University of Helsinki.

Shore, Susanna. 1988. On the so-called Finnish passive. Word 39.3, 151-176.

Sprauniené, Biruté, Auksé Razanovaité \& Erika Jasionytė. 2015. Solving the puzzle of the Lithuanian passive. In: Axel Holvoet \& Nicole Nau, eds., Voice and Argument Structure in Baltic, Amsterdam-Philadelphia: John Benjamins, 323-365.

Sulkala, Helena \& Merja Karjalainen. 1992. Finnish. London-New York: Routledge.

VAagland, Erling M. 1983. Zur Agensangabe im sein-Passiv. In: John O. Askedal, Christen Christensen, Adne Findreng \& Oddleif Leirbukt, eds., Festschrift für Laurits Saltveit zum 7o. Geburtstag am 31. Dezember 1983. Oslo-Bergen-Tromsø: Universitetsforlaget, 194-200. 
Zwicky, Arnold. 1993. Heads, bases, and functors. In: Greville G. Corbett, Norman M. Fraser \& Scott McGlashan, eds., Heads in Grammatical Theory. Cambridge: Cambridge University Press, 292-315.

Žolkovskij, Aleksandr K. \& Igor' A. Mel'čuk. 1967. O semantičeskom sinteze [On semantic synthesis]. Problemy kibernetiki 19, 177-238.

\section{Axel Holvoet}

Birutè Spraunienè

Asta Laugalienè

Vilnius University

Institute for the Languages and Cultures of the Baltic

Universiteto 5

LT-o1131 Vilnius

axel.holvoet@flf.vu.lt

birute.sprauniene@flf.vu.lt

asta.laugaliene@flf.vu.lt

\section{Anna Daugavet}

Vilnius University \& St Petersburg University

Chair of General Linguistics

Universitetskaya nab. 11

RU-199034, St Petersburg

a.daugavet@spbu.ru 